IZA DP No. 8890

Some Surprising Facts about Working Time Accounts and the Business Cycle

Almut Balleer

Britta Gehrke

Christian Merkl

February 2015 


\title{
Some Surprising Facts about Working Time Accounts and the Business Cycle
}

\author{
Almut Balleer \\ RWTH Aachen \\ and IIES, Stockholm University \\ Britta Gehrke \\ Friedrich-Alexander University Erlangen-Nürnberg \\ Christian Merkl \\ Friedrich-Alexander University Erlangen-Nürnberg, \\ Kiel Institute for the World Economy and IZA
}

\section{Discussion Paper No. 8890 \\ February 2015}

\author{
IZA \\ P.O. Box 7240 \\ 53072 Bonn \\ Germany \\ Phone: +49-228-3894-0 \\ Fax: +49-228-3894-180 \\ E-mail: iza@iza.org
}

Any opinions expressed here are those of the author(s) and not those of IZA. Research published in this series may include views on policy, but the institute itself takes no institutional policy positions. The IZA research network is committed to the IZA Guiding Principles of Research Integrity.

The Institute for the Study of Labor (IZA) in Bonn is a local and virtual international research center and a place of communication between science, politics and business. IZA is an independent nonprofit organization supported by Deutsche Post Foundation. The center is associated with the University of Bonn and offers a stimulating research environment through its international network, workshops and conferences, data service, project support, research visits and doctoral program. IZA engages in (i) original and internationally competitive research in all fields of labor economics, (ii) development of policy concepts, and (iii) dissemination of research results and concepts to the interested public.

IZA Discussion Papers often represent preliminary work and are circulated to encourage discussion. Citation of such a paper should account for its provisional character. A revised version may be available directly from the author. 
IZA Discussion Paper No. 8890

February 2015

\section{ABSTRACT}

\section{Some Surprising Facts about Working Time Accounts and the Business Cycle}

Working time accounts (WTAs) allow firms to smooth hours worked over time. This paper analyzes whether this increase in flexibility has also affected how firms adjust employment in Germany. Using a rich microeconomic dataset, we show that firms with WTAs show a similar separation and hiring behavior in response to revenue changes as firms without WTAs. One possible explanation is that firms without WTAs used short-time work instead to adjust hours worked. However, we find that firms with WTAs use short-time work more than firms without WTAs. These findings call into question the popular hypothesis that WTAs were the key driver of the unusually small increase in German unemployment in the Great Recession.

JEL Classification: E20, E24, J20, J30

Keywords: $\quad$ working time accounts, short-time work, business cycles

Corresponding author:

Christian Merkl

Friedrich-Alexander-Universität Erlangen-Nürnberg

Chair of Macroeconomics

Lange Gasse 20

90403 Nürnberg

Germany

E-mail: christian.merkl@fau.de

\footnotetext{
* Almut Balleer is grateful for support from the Knut och Alice Wallenbergs stiftelse KAW 2011.0144. Britta Gehrke and Christian Merkl are grateful for support from the Fritz Thyssen Research Foundation.
} 


\section{Introduction}

In the Great Recession in 2008 and 2009, Germany experienced a severe drop in GDP (6.6 percent from peak to trough) without a substantial rise in unemployment. This experience has become known as the "German labor market miracle" (Burda and Hunt, 2011 and Möller, 2010). Much of the German success has been attributed both to an increase in labor market flexibility before the Great Recession and labor market measures such as short-time work (Boysen-Hogrefe and Groll, 2010, Cahuc and Carcillo, 2011, and Balleer et al., 2014). The use of WTAs has increased substantially in the last decade. In 2009, about one third of all German firms used WTAs covering half of all German employees. ${ }^{1}$ Initially, WTAs were introduced as a cost reduction measure for firms to avoid overtime payment. In the regulated German labor market, WTAs allow firms to flexibly increase working hours in good times and to reduce them in bad times without additional costs (see appendix for details). Hence, WTAs can exhibit stabilizing effects on employment over the business cycle as they may help firms to better respond to aggregate shocks. Large surpluses in WTAs might have buffered the increase in unemployment at the outset of the Great Recession (Burda and Hunt, 2011).

Quantitative evidence on the effects of WTAs on firms' business cycle adjustment is relatively scarce. ${ }^{2}$ We use data from the Institute for Employment Research (IAB) establishment panel to analyze whether firms with WTAs behave differently over the business cycle compared to firms without WTAs. Specifically, we estimate the change in the hiring and separation rates to a one percent change in expected revenues for firms with and without WTAs. To rule out selection of firms over the cycle, we investigate the within-firm variation over time. To control for the possibility that firms with WTAs systematically differ from firms without, we include various firm characteristics such as sector and size into our specification. Using interaction terms, we allow for different responses conditional on firm characteristics. We find no evidence that firms with WTAs adjust hiring and separations differently over the business cycle than firms without.

Against this background, we ask whether firms that do not use WTAs employ alterna-

\footnotetext{
${ }^{1}$ Source: IAB establishment panel.

${ }^{2}$ Notable exceptions are Boeri and Brücker (2011), Bellmann and Gerner (2011), and Bellmann et al. (2012). In contrast to these studies, we explicitly focus on the interaction between WTAs and short-time work as well as the pronounced heterogeneity between firms with and without WTAs (e.g., with respect to size and sector).
} 
tive measures such as short-time work (STW) instead. Burda and Hunt (2011, p. 314 f.) argue: "The increased use of privately negotiated working time accounts appears to have cheapened private adjustment along the intensive margin and substituted for the more traditional government short-time work." If Burda and Hunt's substitutability hypothesis holds on the aggregate level, we also expect to find evidence for this hypothesis on the disaggregated level. Note that a firm cannot use both WTAs and STW to adjust hours worked at the same point in time. However, over a year, a firm may use WTAs and STW subsequently. If WTAs positively affect the flexibility of a firm's labor market adjustment to shocks, we expect firms with WTAs to use STW less. Surprisingly, we find that firms with WTAs do not use STW less in response to revenue changes, if anything, they use it more. In order to rule out that this result is driven by the fact that firms using WTAs might be hit harder by a recession than firms that do not use WTAs, we control for average revenue volatility over and above other firms characteristics.

The rest of the paper is organized as follows: Section 2 discusses the dataset and the econometric specifications. Section 3 shows results for the hiring and firing behavior over the business cycle for firms with and without WTAs. Section 4 analyzes whether firms with and without WTAs use STW differently over the cycle. Section 5 briefly concludes.

\section{Data and specification}

To investigate the differential behavior of firms with and without WTAs, we employ the German Institute for Employment Research (IAB) establishment panel, a representative panel data set that surveys information from almost 16,000 personal interviews with high ranked managers (see appendix for data description). We use data for the years 2006, 2009 and 2010, since information on both WTAs and STW is only available in these years.

Table 1 shows descriptive statistics for establishments with and without WTAs. The establishments are remarkably different. Establishments that use WTAs have on average more employees and higher revenues than establishments that do not use WTAs. Establishments with WTAs are more export oriented and employ a higher share of skilled workers. In addition, labor in establishments with WTAs is more formally organized (e.g., with works councils and collective agreements), while establishments without WTAs are 
more likely to be family owned. On average, establishments with WTAs use more STW and have somewhat smaller flow rates than establishments without WTAs.

\begin{tabular}{|c|c|c|}
\hline & $\begin{array}{l}\text { WTA establish- } \\
\text { ments }\end{array}$ & $\begin{array}{l}\text { non-WTA } \\
\text { establishments }\end{array}$ \\
\hline number of employees & $\begin{array}{l}305.33 \\
(21,395)\end{array}$ & $\begin{array}{l}27.44 \\
(26,456)\end{array}$ \\
\hline establishment revenue & $\begin{array}{l}65 \text { mio. } \\
(12,953)\end{array}$ & $\begin{array}{l}5.2 \text { mio. } \\
(16,209)\end{array}$ \\
\hline export share (in percent) & $\begin{array}{l}12.76 \\
(16,620)\end{array}$ & $\begin{array}{l}3.44 \\
(22,753)\end{array}$ \\
\hline skilled workers (in percent of employment) & $\begin{array}{l}77.48 \\
(21,387)\end{array}$ & $\begin{array}{l}57.45 \\
(26,454)\end{array}$ \\
\hline high skilled workers (in percent of employment) & $\begin{array}{l}14.00 \\
(21,388)\end{array}$ & $\begin{array}{l}7.60 \\
(26,454)\end{array}$ \\
\hline temporary workers (in percent of employment) & $\begin{array}{l}5.88 \\
(21,221)\end{array}$ & $\begin{array}{l}4.76 \\
(26,305)\end{array}$ \\
\hline agency workers (in percent of employment) & 2.34 & 0.50 \\
\hline share of establishments with works council & $\begin{array}{l}61.98 \\
(21,343)\end{array}$ & $\begin{array}{l}9.48 \\
(26,385)\end{array}$ \\
\hline share of establishments with collective agreement & $\begin{array}{l}68.59 \\
(21,343)\end{array}$ & $\begin{array}{l}32.22 \\
(26,385)\end{array}$ \\
\hline share of establishments with sole proprietorship & 6.76 & 48.32 \\
\hline share of incorporated enterprises & 6.15 & 1.03 \\
\hline share of establishments with professional management & 58.67 & 14.52 \\
\hline short-time workers (in percent of employment) & $\begin{array}{l}6.59 \\
(21,395)\end{array}$ & $\begin{array}{l}2.15 \\
(26,456)\end{array}$ \\
\hline hiring rate & 4.37 & 5.09 \\
\hline separation rate & 3.76 & 4.35 \\
\hline
\end{tabular}

Table 1: Establishment characteristics on WTA and non-WTA establishments in IAB establishment panel (year 2006, 2009, 2010). A WTA establishment is defined as an establishment that always operated WTAs, a non-WTA establishment never operated WTAs in all years included in the sample. See appendix for a detailed variable description.

To assess the business cycle behavior of establishments, we estimate the effect of 
changes in revenue $x_{i t}$ of establishment $i$ in year $t$ on its separation rate, hiring rate and the use of STW separately (indexed by $j$ )

$$
y_{i t}^{(j)}=x_{i t} \beta_{1}^{(j)}+x_{i t} D_{i t}^{w t a} \beta_{2}^{(j)}+z_{i t} \beta_{3}^{(j)}+\alpha_{i}^{(j)}+\gamma_{t}^{(j)}+u_{i t}^{(j)}
$$

where $y_{i t}^{(j)}$ represents separated workers, hired workers or workers on short-time work as a fraction of employment in establishment $i$ in year $t$ reported in June of year $t .^{3}$ On the right hand side, $x_{i t}$ represents the corresponding establishment revenue (in logs) which is measured as expected revenue for year $t$ reported in June of year $t$. Revenue is further interacted with a dummy indicating whether the establishment uses working time accounts $\left(D_{i t}^{w t a}=1\right)$ or not $\left(D_{i t}^{w t a}=0\right)$. We therefore estimate a semi-elasticity, i.e., the effects of a one percent change in revenue on the labor adjustment margin (measured in percentage points). The estimated coefficients of the interaction terms allow a straightforward test and comparison of differences in this semi-elasticity between establishments that use WTAs and those that do not. For a straightforward interpretation of the interaction term and to avoid selection into WTAs in the Great Recession, we restrict the sample to firms that always or never have WTAs in all years in the sample.

In addition, we control for several establishment characteristics $z_{i t}$ (see the covariates listed in Table 1). In this way, we explicitly take into account that establishments with WTAs may adjust labor input differently compared to establishments that do not use WTAs due to their different size, sector or degree of labor organization. In addition, time fixed effects, $\gamma_{t}^{(j)}$, control for aggregate year effects and establishment fixed effects, $\alpha_{i}^{(j)}$, control for time-invariant unobserved establishment heterogeneity. We therefore estimate the effects of changes in revenue within a firm on the changes in hiring, firing and STW use relative to the average usage on the firm level.

To investigate heterogeneity further, we explore additional specifications. We allow for a different response to revenue changes conditional not only on WTAs, but also on further establishment characteristics, e.g., size and sector. Consequently, we add interactions between revenue and alternative establishment characteristics and two-way interactions

\footnotetext{
${ }^{3}$ This approach follows Balleer et al. (2014) who investigate the effect of revenue changes on STW usage, but not WTAs explicitly, nor the interaction with STW, nor the effect on flow rates.
} 
with revenue, WTAs, and these characteristics

$$
y_{i t}^{(j)}=x_{i t} \beta_{1}^{(j)}+x_{i t} D_{i}^{w t a} \beta_{2}^{(j)}+\mathbf{z}_{i t} \beta_{3}^{(j)}+x_{i t} \mathbf{D}_{i}^{\text {controls }}\left(\beta_{4}^{(j)}+D_{i}^{w t a} \beta_{5}^{(j)}\right)+\alpha_{i}^{(j)}+\gamma_{t}^{(j)}+u_{i t}^{(j)},
$$

where the vector $\mathbf{D}_{i}^{\text {controls }}$ comprises dummy variables for the respective establishment characteristic in categories. We consider interactions with revenue, WTAs, and establishment size, sector, export orientation, labor organization (works council and collective wage agreements), and average revenue volatility (prior to 2006). ${ }^{4}$ Revenue volatility controls for whether establishments are particularly exposed to revenue changes, e.g., due to the type of products they sell, and, hence, more accustomed to adjusting production and input.

\section{Working time accounts and labor market flows over the cycle}

Before 2009, firms had accumulated a substantial surplus of on average 72 hours in their WTAs (see Herzog-Stein and Zapf, 2014). The IAB establishment panel does not contain any information on the WTA balance (only on the existence of WTAs). ${ }^{5}$ But even if only a certain fraction of establishments had substantial surpluses, they should affect the difference in adjustment behavior within the subsample. Table 2 shows that a one percent drop in revenue leads establishments to increase their separation rate by approximately 0.018 percentage points. ${ }^{6}$ Interestingly, this effect is not significantly different between

\footnotetext{
${ }^{4}$ We classify size in less than 10,10 to 49,50 to 199 , and 200 and more employees and sector in manufacturing, construction, services and others. The following categories measure export orientation: no exports, less than 50 percent of revenue generated from exports, and 50 and more percent of revenue generated from exports. We measure revenue volatility prior to 2006 as the standard deviation of revenue (in logs) in each establishment. We classify revenue volatility between $0-16,17-31,32-45$, and more than 45 percent. This classification ensures that each category captures approximately 25 percent of establishments.

${ }^{5}$ The IAB provides an aggregate series of surplus hours on WTAs that infers WTA balances from aggregate variables such as GDP, overtime, standard weekly hours, and sick days (Zapf, 2012). Given that this data is not derived from establishment level data, it does not contain any information for our analysis.

${ }^{6}$ This number implies that a one standard deviation drop of revenue generates an increase in the separation rate of 0.36 percentage points.
} 
establishments that use WTAs and establishments that do not. ${ }^{7}$

Interacting revenue and WTAs with dummies for different size classes (see Eq. 2) reveals that small, medium and large establishments react differently to changes in revenue with respect to their separation behavior. However, even though the point estimates suggest that small establishments with WTAs fire less in recessions than small establishments without WTAs, the differences are not statistically significant. The only exception is the case of very large establishments. However, the estimate for very large establishments without WTAs is very imprecise due to only 124 observations. The difference between establishments with and without WTAs is therefore hard to interpret. Similar to the results by size, the responses of separation rates to changes in revenue differ across sectors. But again, the responses do not significantly differ between establishments that use WTAs and establishments that do not, except for a borderline significant positive effect in the construction sector.

Next, we analyze the response of the hiring rate with respect to revenue changes. We obtain no statistically significant results, neither for WTA, nor for non-WTA establishments. This finding implies that establishments adjust mainly via separations to revenue shocks (see appendix, Table 6 for details).

\section{Working time accounts and short-time work over the cycle}

In addition to WTAs, short-time work constitutes a policy measure that enhances the flexibility of hours in Germany. STW subsidizes wage payments when firms reduce hours worked of their employees if firms show credibly that they face a short-fall in demand. An open question is whether and how the use of WTAs is related to the use of STW in the same firm. The fact that we find no difference in separations between establishments with

\footnotetext{
${ }^{7}$ While Boeri and Brücker (2011) find a small, but positive effect of WTAs on employment with instrumental variables, Bellmann et al. (2012) find negative effects of WTAs on labor market flows. However, they argue that their estimates may be imprecise. Bellmann and Gerner (2011) concentrate on employment effects in the Great Recession only. We show that no systematic difference exists between firms that continuously apply WTAs and those that do not. The same holds if we differentiate by wage type, existence of works' council, export status, and revenue volatility. Herzog-Stein and Zapf (2014) argue based on a survey of works councils that firms did not apply WTAs systematically different in the Great Recession compared to normal times.
} 


\begin{tabular}{|c|c|c|c|c|c|c|c|}
\hline \multirow[b]{2}{*}{ baseline } & & \multicolumn{2}{|c|}{ WTA establishments } & \multicolumn{2}{|c|}{ non-WTA establishments } & \multicolumn{2}{|c|}{ difference } \\
\hline & & $-1.86^{* * *}$ & {$[0.67]$} & $-1.83^{* *}$ & {$[0.87]$} & -0.03 & {$[1.08$} \\
\hline by size & $\begin{array}{r}<10 \\
{[10-50)} \\
{[50-200)} \\
>200\end{array}$ & $\begin{array}{l}-1.11 \\
-2.37^{* * *} \\
-1.85^{* *} \\
-1.78^{* * *}\end{array}$ & $\begin{array}{l}{[1.48]} \\
{[0.83]} \\
{[0.73]} \\
{[0.63]}\end{array}$ & $\begin{array}{l}-1.80^{*} \\
-3.03^{* * *} \\
-1.27 \\
0.89\end{array}$ & $\begin{array}{l}{[0.99]} \\
{[0.91]} \\
{[0.99]} \\
{[0.96]}\end{array}$ & $\begin{array}{c}0.69 \\
0.67 \\
-0.58 \\
-2.67^{* *} \\
\quad p=0\end{array}$ & $\begin{array}{l}{[1.77} \\
{[1.23} \\
{[1.22} \\
{[1.13} \\
1\end{array}$ \\
\hline by sector & $\begin{array}{r}\text { manufacturing } \\
\text { services } \\
\text { construction } \\
\text { others }\end{array}$ & $\begin{array}{l}-1.71^{\text {*** }} \\
-1.86^{\text {** }} \\
-1.06 \\
-1.82\end{array}$ & $\begin{array}{l}{[0.65]} \\
{[0.83]} \\
{[0.83]} \\
{[0.90]}\end{array}$ & $\begin{array}{l}-2.79^{* *} \\
-0.68 \\
-4.40^{* *} \\
-0.66\end{array}$ & $\begin{array}{l}{[1.24]} \\
{[0.88]} \\
{[1.75]} \\
{[1.05]}\end{array}$ & $\begin{array}{c}1.07 \\
-1.18 \\
3.34^{*} \\
-1.16 \\
\quad p=0\end{array}$ & $\begin{array}{l}{[1.39} \\
{[1.20} \\
{[1.94} \\
{[1.38} \\
9\end{array}$ \\
\hline by wages & $\begin{array}{l}\text { individual wages } \\
\text { collective wages }\end{array}$ & $\begin{array}{l}-1.82^{* * *} \\
-1.88^{* * *}\end{array}$ & $\begin{array}{l}{[0.69]} \\
{[0.67]}\end{array}$ & $\begin{array}{l}-1.93^{* *} \\
-1.33\end{array}$ & $\begin{array}{l}{[0.90]} \\
{[0.83]}\end{array}$ & $\begin{array}{c}0.12 \\
-0.56 \\
\quad p=0\end{array}$ & $\begin{array}{l}{[1.13} \\
{[1.06} \\
3\end{array}$ \\
\hline by council & $\begin{array}{r}\text { no works council } \\
\text { council exists }\end{array}$ & $\begin{array}{l}-2.05^{* *} \\
-1.64^{* *}\end{array}$ & $\begin{array}{l}{[0.81]} \\
{[0.66]}\end{array}$ & $\begin{array}{l}-1.84^{* *} \\
-1.74^{*}\end{array}$ & $\begin{array}{l}{[0.89]} \\
{[0.79]}\end{array}$ & $\begin{array}{c}-0.21 \\
0.10 \\
p=0\end{array}$ & $\begin{array}{l}{[1.17} \\
{[1.01} \\
9\end{array}$ \\
\hline by exports & $\begin{array}{r}\text { no exports } \\
1-49.9 \% \text { of revenue } \\
50-100 \% \text { of revenue }\end{array}$ & $\begin{array}{l}-1.88^{* * *} \\
-1.70^{* *} \\
-2.06^{* * *}\end{array}$ & $\begin{array}{l}{[0.70]} \\
{[0.68]} \\
{[0.72]}\end{array}$ & $\begin{array}{l}-1.80^{* *} \\
-2.25^{* * *} \\
-1.52\end{array}$ & $\begin{array}{l}{[0.89]} \\
{[0.86]} \\
{[0.92]}\end{array}$ & $\begin{array}{r}-0.08 \\
0.55 \\
-0.54 \\
p=0\end{array}$ & $\begin{array}{l}{[1.13} \\
{[1.09} \\
{[1.15} \\
8\end{array}$ \\
\hline by revenue std. & $\begin{array}{r}0-0.16 \\
0.17-0.31 \\
0.32-0.45 \\
0.45+\end{array}$ & $\begin{array}{l}-1.00 \\
-2.82^{* *} \\
-1.55 \\
-1.35\end{array}$ & $\begin{array}{l}{[1.49]} \\
{[1.42]} \\
{[1.46]} \\
{[1.59]}\end{array}$ & $\begin{array}{l}0.95 \\
-0.02 \\
-3.19^{*} \\
-3.37^{*}\end{array}$ & $\begin{array}{l}{[1.30]} \\
{[2.10]} \\
{[1.65]} \\
{[1.91]}\end{array}$ & $\begin{array}{c}-1.95 \\
-2.80 \\
1.64 \\
2.03 \\
p=\end{array}$ & $\begin{array}{l}{[1.96} \\
{[2.52} \\
{[2.20} \\
{[2.49} \\
18\end{array}$ \\
\hline
\end{tabular}

Table 2: Separation reaction with respect to revenue changes. Robust standard errors in parenthesis are clustered at the establishment level. Establishment size is measured by the number of employees. p-values refer to an F-test of the overall significance of all WTA interaction terms. Detailed estimation output can be found in the appendix in Table 5.

and without WTAs could suggest that this outcome is driven by a different usage of STW over the cycle. Put differently, WTAs and STW could be substitutes with respect to the hours adjustment (as suggested by Boeri and Brücker, 2011 or Burda and Hunt, 2011).

The descriptives in Table 1 demonstrate that establishments with WTAs use STW 
more and, hence, that these two labor market institutions are clearly no substitutes on average. Here, we ask whether establishments with and without WTAs use STW in a different way over the cycle.

Table 3 shows the STW usage of different types of establishments in response to a one percent change in revenue. Establishments with WTAs set a higher fraction of their workers on STW compared to establishments without WTAs. As a result, also over the business cycle, establishments that use the formal hours adjustment WTA use STW policy more.

When we disaggregate the results with respect to size, sector, and further establishment characteristics, the point estimates for the STW semi-elasticities are the largest for large, exporting establishments with a works council and for the manufacturing sector. This finding is in line with the conventional view that STW is predominantly used by large manufacturing firms. For most subgroups, the difference of semi-elasticities is statistically significant (at the 1 percent level in many cases). Thus, we do not find any evidence (in any subgroup) that WTAs and STW act as substitutes. This is still the case if we divide the estimated semi-elasticities by the average STW usage in establishments with and without WTAs, i.e., if we calculate elasticities instead of semi-elasticities. ${ }^{8}$

\section{Conclusions}

This paper reveals several surprising facts on the relationship between WTAs and firms' labor adjustment behavior. First, firms' hiring and separation behavior over the business cycle is not affected by whether they operate WTAs or not. This finding sounds a cautionary note on the widely held view that the use of WTAs was a key driver of the German labor market miracle. The missing job losses in Germany are potentially explained by other exceptional factors such as the preceding wage moderation or the nature of the aggregate shock. Note that our findings do not rule out the argument of Burda and Hunt (2011) that underhiring and therefore overtime hours in the preceding boom had an important impact on the German labor market miracle. However, our analysis provides no

\footnotetext{
${ }^{8}$ In our view, semi-elasticities are more appropriate and easier to interpret. When STW increases from 0.5 to 1.5 percent of the workforce, we obtain the same semi-elasticity as for an increase from 2 to 3 percent of the workforce. By contrast, the elasticity would increase three times as much in the former case. Detailed results on elasticities are available upon request.
} 


\begin{tabular}{|c|c|c|c|c|c|c|c|}
\hline \multirow[b]{2}{*}{ baseline } & & \multicolumn{2}{|c|}{ WTA establishments } & \multicolumn{2}{|c|}{ non-WTA establishments } & \multicolumn{2}{|c|}{ difference } \\
\hline & & $-11.90^{* * *}$ & {$[1.73]$} & $-2.07^{* * *}$ & {$[0.71]$} & $-9.84^{* * *}$ & [1.88] \\
\hline by size & $\begin{array}{r}<10 \\
{[10-50)} \\
{[50-200)} \\
>200\end{array}$ & $\begin{array}{c}-8.61^{* *} \\
-11.72^{* * *} \\
-13.48^{* * *} \\
-12.51^{* * *}\end{array}$ & $\begin{array}{l}{[3.77]} \\
{[1.94]} \\
{[1.95]} \\
{[2.21]}\end{array}$ & $\begin{array}{l}-1.14 \\
-5.61^{* * *} \\
-4.51^{*} \\
-6.29^{* * *}\end{array}$ & $\begin{array}{l}{[0.71]} \\
{[1.47]} \\
{[2.36]} \\
{[2.18]}\end{array}$ & $\begin{array}{l}-7.47^{*} \\
-5.94^{* *} \\
-8.97^{* * *} \\
-6.22^{* *} \\
\quad p=0.0\end{array}$ & $\begin{array}{l}{[3.84]} \\
{[2.43]} \\
{[3.05]} \\
{[3.07]}\end{array}$ \\
\hline by sector & $\begin{array}{r}\text { manufacturing } \\
\text { services } \\
\text { construction } \\
\text { others }\end{array}$ & $\begin{array}{c}-12.87^{* * *} \\
-10.08^{* * *} \\
-10.52^{* * *} \\
-9.76^{* *}\end{array}$ & $\begin{array}{l}{[2.02]} \\
{[1.60]} \\
{[1.92]} \\
{[1.67]}\end{array}$ & $\begin{array}{l}-4.71^{* * *} \\
-1.11 \\
-3.16^{* * *} \\
-3.31^{* *}\end{array}$ & $\begin{array}{l}{[1.20]} \\
{[0.70]} \\
{[1.13]} \\
{[1.34]}\end{array}$ & $\begin{array}{c}-8.15^{* * *} \\
-8.97^{* * *} \\
-7.36^{* * *} \\
-6.45^{* * *} \\
\quad p=0.0\end{array}$ & $\begin{array}{l}{[2.35]} \\
{[1.75]} \\
{[2.23]} \\
{[2.13]}\end{array}$ \\
\hline by wages & $\begin{array}{l}\text { individual wages } \\
\text { collective wages }\end{array}$ & $\begin{array}{l}-12.41^{* * *} \\
-11.49^{* * *}\end{array}$ & $\begin{array}{l}{[1.77]} \\
{[1.80]}\end{array}$ & $\begin{array}{l}-1.78^{* *} \\
-3.38^{* * *}\end{array}$ & $\begin{array}{l}{[0.70]} \\
{[0.80]}\end{array}$ & $\begin{array}{r}-10.63^{* * *} \\
-8.12^{* * *} \\
p=0.0\end{array}$ & $\begin{array}{l}{[1.85]} \\
{[1.99]}\end{array}$ \\
\hline by council & $\begin{array}{r}\text { no works council } \\
\text { council exists }\end{array}$ & $\begin{array}{l}-10.62^{* * *} \\
-13.26^{* * *}\end{array}$ & $\begin{array}{l}{[1.66]} \\
{[2.22]}\end{array}$ & $\begin{array}{l}-1.81^{* *} \\
-4.78^{* * *}\end{array}$ & $\begin{array}{l}{[0.70]} \\
{[1.44]}\end{array}$ & $\begin{array}{r}-8.82^{* * *} \\
-8.48^{* * *} \\
\quad p=0.0\end{array}$ & $\begin{array}{l}{[1.81]} \\
{[2.44]}\end{array}$ \\
\hline by exports & $\begin{array}{r}\text { no exports } \\
1-49.9 \% \text { of revenue } \\
50-100 \% \text { of revenue }\end{array}$ & $\begin{array}{l}-11.68^{* * *} \\
-11.00^{* * *} \\
-14.43^{* * *}\end{array}$ & $\begin{array}{l}{[1.71]} \\
{[1.87]} \\
{[2.08]}\end{array}$ & $\begin{array}{l}-2.08^{* * *} \\
-1.90^{* *} \\
-3.04^{* *}\end{array}$ & $\begin{array}{l}{[0.69]} \\
{[0.95]} \\
{[1.53]}\end{array}$ & $\begin{array}{c}-9.60^{* * *} \\
-9.10^{* * *} \\
-11.39^{* * *} \\
\quad p=0.0\end{array}$ & $\begin{array}{l}{[1.85]} \\
{[2.10]} \\
{[2.59]}\end{array}$ \\
\hline by revenue std. & $\begin{array}{r}0-0.16 \\
0.17-0.31 \\
0.32-0.45 \\
0.45+\end{array}$ & $\begin{array}{c}-11.19^{* * *} \\
-19.89^{* * *} \\
-15.97^{* * *} \\
-7.48^{* *}\end{array}$ & $\begin{array}{l}{[3.19]} \\
{[3.96]} \\
{[3.76]} \\
{[3.68]}\end{array}$ & $\begin{array}{l}-5.08^{*} \\
-0.62 \\
-3.59^{* *} \\
-1.39\end{array}$ & $\begin{array}{l}{[2.69]} \\
{[1.46]} \\
{[1.75]} \\
{[1.32]}\end{array}$ & $\begin{array}{c}-6.11 \\
-19.28^{* * *} \\
-12.37^{* * *} \\
-6.08 \\
\quad p=0.0\end{array}$ & $\begin{array}{l}{[4.17]} \\
{[4.22]} \\
{[4.17]} \\
{[3.92]}\end{array}$ \\
\hline
\end{tabular}

Table 3: Short-time work reaction with respect to revenue changes. Robust standard errors in parenthesis are clustered at the establishment level. Establishment size is measured by the number of employees. p-values refer to an F-test of the overall significance of all WTA interaction terms. Detailed estimation output can be found in the appendix in Table 7.

signs that WTAs were a necessary condition for the intertemporal transfer of working hours in the recession.

Second, firms with WTAs do not only use more STW on average. They also use STW in a more cyclical manner. This finding calls into question the hypothesis that WTAs 
substituted for STW with respect to the adjustment along the intensive margin. Establishments without WTAs may have utilized other informal ways of transferring working hours over time. ${ }^{9}$ These informal mechanisms may be facilitated because these establishments are substantially smaller and act in different industrial relations regimes. In the end, even though we control for (un)observed heterogeneity carefully, there may be underlying differences between firms with and without WTAs that affect the estimated semi-elasticties directly. An example are different production technologies that determine how capital and labor are utilized and substituted. Therefore, some firms may react differently to upand downturns in demand, e.g., due to the type of products they sell, and, hence, show a different attitude towards input adjustments. It is certainly an interesting topic for future research how production functions and measures such as WTAs or STW interact in the labor adjustment of firms to economic shocks.

\footnotetext{
${ }^{9}$ As we have no information on the actual number of working hours in the IAB establishment panel, this hypothesis is not directly testable.
} 


\section{References}

Balleer, A., B. Gehrke, W. Lechthaler, And C. Merkl (2014): "Does ShortTime Work Save Jobs? A Business Cycle Analysis," CESifo Working Paper Series, 4640 .

Bellmann, L. AND H. Gerner (2011): "Reversed Roles? Wage and Employment Effects of the Current Crisis," in Who Loses in the Downturn? Economic Crisis, Employment and Income Distribution, ed. by H. Immervoll, A. Peichl, and K. Tatsiramos, Research in Labor Economics, vol. 32, 181-206.

Bellmann, L., H. Gerner, And R. Upward (2012): “The Response of German Establishments to the 2008-2009 Economic Crisis," OECD Social, Employment and Migration Working Papers, 137.

BOERI, T. AND H. BRÜCKER (2011): "Short-Time Work Benefits Revisited: Some Lessons from the Great Recession," Economic Policy, 26, 697-765.

Boysen-Hogrefe, J. AND D. Groll (2010): “The German Labour Market Miracle," National Institute Economic Review, 214, R38.

Burda, M. AND J. HunT (2011): "What Explains the German Labor Market Miracle in the Great Recession?" Brookings Papers on Economic Activity, Spring 2011, 273-319.

Cahuc, P. And S. CARcillo (2011): "Is Short-Time Work a Good Method to Keep Unemployment Down?” Nordic Economic Policy Review, 1.

HerzoG-SteIn, A. AND I. ZAPF (2014): "Navigating the Great Recession: The Impact of Working-Time Accounts in Germany," Industrial and Labor Relations Review, 67, 891-925.

MÖLlER, J. (2010): "The German Labor Market Response in the World Recession De-mystifying a Miracle," Journal for Labour Market Research, 42, 325-336.

ZAPF, I. (2012): "Flexibilität am Arbeitsmarkt durch Überstunden und Arbeitszeitkonten - Messkonzepte, Datenquellen und Ergebnisse im Kontext der IABArbeitszeitrechnung," IAB-Forschungsbericht, 3/2012. 


\section{A Description of the institutions working time account and short-time work}

Working time accounts ("Arbeitszeitkonten"): Working time accounts are firm-level agreements that allow employers to use overtime without an additional compensation for the employee under the condition that working time is reduced by equal hours within an agreed window of time (typically approximately one year). Equally, working hours may fall below contract hours without wage cuts, if they are made up in due time. A worker with surplus hours cannot be laid off or be sent on short-time work without previously compensating the worker at overtime rates.

Working time accounts have become increasingly popular in Germany (also due to more flexible legislation). In the late 1990's, 18 percent of firms had a working time account, in 2011, 34 percent of all employers had a working time account program. Given that mostly large firms operate working time accounts, approximately 54 percent of all employees had access to working time accounts. See, e.g., Herzog-Stein and Zapf (2014) for a more detailed description of working time accounts.

Short-time work ("Kurzarbeit"): In contrast to working time accounts that are agreed on at the firm level, short-time work is administered by the employment agency. A firm in financial difficulties may apply for short-time work. If admitted, the firm reduces working hours and wages, accordingly. Workers are compensated for between 60 and 67 percent of the net wage loss by the employment agency. See, e.g., Burda and Hunt (2011) for a more detailed discussion. Interestingly, short-time work has an automatic and a discretionary policy component. The latter implies that the government expands short-time work in recessions by facilitating the rules. Balleer et al. (2014) disentangle the effects of these two components. 


\section{B Data description, variable definition, and detailed esti- mation results}

The Institute for Employment Research (IAB) establishment panel is a representative German establishment level panel data set that contains establishment level data from approximately 16,000 personal interviews with high ranked managers each year. Data access was provided via on-site use at the Research Data Centre (FDZ) of the German Federal Employment Agency (BA) at the Institute for Employment Research (IAB) and subsequently through remote data access. Table 4 summarizes the variable definition of the variables used in this paper. Establishments report the number of short-time workers, new hirings and separations in the first half of each year in the sample. Table 4 also contains all control variables used in the estimations. 


\begin{tabular}{ll}
\hline Variable & Definition \\
\hline revenue & $\begin{array}{l}\text { Revenue expectations for year } t \text { as reported by establishment end of June } \\
\text { in year } t \text { (in logs) } \\
\text { Number of employees as reported by the establishment end of June of } \\
\text { employees }\end{array}$ \\
year $t-1$ (also as dummy with 4 categories as defined in text) \\
Establishment operates working time accounts in all years in the sample \\
(dummy yes (1)/no)
\end{tabular}

Table 4: Variable definition. 


\begin{tabular}{|c|c|c|c|c|c|}
\hline & \multicolumn{3}{|c|}{ Interaction with WTA only and size } & \multicolumn{2}{|c|}{ Interaction with sector } \\
\hline & (1) & (2) & (3) & & (4) \\
\hline $\log$ revenue & $\begin{array}{l}-1.819^{* *} \\
{[0.83]}\end{array}$ & $\begin{array}{c}-1.828^{* *} \\
{[0.87]}\end{array}$ & $\begin{array}{c}-1.802^{*} \\
{[0.99]}\end{array}$ & $\log$ revenue & $\begin{array}{c}-0.678 \\
{[0.88]}\end{array}$ \\
\hline revenue $\times$ WTA & $\begin{array}{c}-0.144 \\
{[1.05]}\end{array}$ & $\begin{array}{r}-0.027 \\
{[1.08]}\end{array}$ & $\begin{array}{r}0.688 \\
{[1.77]}\end{array}$ & revenue $\times$ WTA & $\begin{array}{c}-1.183 \\
{[1.20]}\end{array}$ \\
\hline revenue $\times D_{2}^{e m p}$ & & & $\begin{array}{c}-1.235 \\
{[0.90]}\end{array}$ & revenue $\times D_{2}^{\text {sector }}$ & $\begin{array}{c}-2.110^{* * *} \\
{[1.22]}\end{array}$ \\
\hline revenue $\times D_{3}^{e m p}$ & & & $\begin{array}{l}0.528 \\
{[1.20]}\end{array}$ & revenue $\times D_{3}^{\text {sector }}$ & $\begin{array}{l}-3.721^{* * *} \\
{[1.51]}\end{array}$ \\
\hline revenue $\times D_{4}^{e m p}$ & & & $\begin{array}{l}2.689^{* *} \\
{[1.23]}\end{array}$ & revenue $\times D_{4}^{\text {sector }}$ & $\begin{array}{l}0.020 \\
{[0.85]}\end{array}$ \\
\hline revenue $\times D_{2}^{e m p} \times \mathrm{WTA}$ & & & $\begin{array}{c}-0.020 \\
{[1.65]}\end{array}$ & revenue $\times D_{2}^{\text {sector }} \times$ WTA & $\begin{array}{l}2.258^{*} \\
{[1.31]}\end{array}$ \\
\hline revenue $\times D_{3}^{e m p} \times \mathrm{WTA}$ & & & $\begin{array}{c}-1.264 \\
{[1.87]}\end{array}$ & revenue $\times D_{3}^{\text {sector }} \times$ WTA & $\begin{array}{l}4.522^{* * *} \\
{[1.68]}\end{array}$ \\
\hline revenue $\times D_{4}^{e m p} \times$ WTA & & & $\begin{array}{c}-3.360^{*} \\
{[1.88]}\end{array}$ & revenue $\times D_{4}^{\text {sector }} \times$ WTA & $\begin{array}{l}0.0225 \\
{[0.98]}\end{array}$ \\
\hline employees & $\begin{array}{l}0.005^{* * *} \\
{[0.002]}\end{array}$ & $\begin{array}{l}0.005^{* * *} \\
{[0.002]}\end{array}$ & $\begin{array}{l}0.005^{* * *} \\
{[0.002]}\end{array}$ & employees & $\begin{array}{l}0.005^{* *} \\
{[0.002]}\end{array}$ \\
\hline works council & & $\begin{array}{c}0.707 \\
{[0.78]}\end{array}$ & $\begin{array}{c}0.650 \\
{[0.78]}\end{array}$ & works council & $\begin{array}{l}0.728 \\
{[0.81]}\end{array}$ \\
\hline collective wages & & $\begin{array}{c}-0.228 \\
{[0.63]}\end{array}$ & $\begin{array}{r}-0.267 \\
{[0.63]}\end{array}$ & collective wages & $\begin{array}{c}-0.139 \\
{[0.64]}\end{array}$ \\
\hline agency workers & & $\begin{array}{c}-0.027^{* * *} \\
{[0.01]}\end{array}$ & $\begin{array}{c}-0.028^{* * *} \\
{[0.01]}\end{array}$ & agency workers & $\begin{array}{c}-0.028^{* * *} \\
{[0.01]}\end{array}$ \\
\hline temporary workers & & $\begin{array}{c}-0.006 \\
{[0.02]}\end{array}$ & $\begin{array}{c}-0.005 \\
{[0.02]}\end{array}$ & temporary workers & $\begin{array}{c}-0.005 \\
{[0.02]}\end{array}$ \\
\hline high skilled & & $\begin{array}{c}-0.003 \\
{[0.03]}\end{array}$ & $\begin{array}{c}-0.003 \\
{[0.03]}\end{array}$ & high skilled & $\begin{array}{c}-0.002 \\
{[0.03]}\end{array}$ \\
\hline export share & & $\begin{array}{c}-0.013 \\
{[0.02]}\end{array}$ & $\begin{array}{c}-0.013 \\
{[0.02]}\end{array}$ & export share & $\begin{array}{c}-0.013 \\
{[0.02]}\end{array}$ \\
\hline women & & $\begin{array}{c}-0.056^{* * *} \\
{[0.02]}\end{array}$ & $\begin{array}{c}-0.056^{* * *} \\
{[0.02]}\end{array}$ & women & $\begin{array}{c}-0.061^{* * *} \\
{[0.02]}\end{array}$ \\
\hline year $=2009$ & $\begin{array}{c}0.346 \\
{[0.23]}\end{array}$ & $\begin{array}{c}0.364 \\
{[0.24]}\end{array}$ & $\begin{array}{c}0.342 \\
{[0.24]}\end{array}$ & year $=2009$ & $\begin{array}{c}0.290 \\
{[0.23]}\end{array}$ \\
\hline year $=2010$ & $\begin{array}{c}0.010 \\
{[0.24]}\end{array}$ & $\begin{array}{c}-0.011 \\
{[0.24]}\end{array}$ & $\begin{array}{c}-0.020 \\
{[0.24]}\end{array}$ & year $=2010$ & $\begin{array}{r}-0.090 \\
{[0.25]}\end{array}$ \\
\hline observations & 10,394 & 10,135 & 10,135 & observations & 9,822 \\
\hline establishments & 4,228 & 4,211 & 4,211 & establishments & 4,181 \\
\hline$R^{2}$ (within) & 0.01 & 0.01 & 0.01 & $R^{2}$ (within) & 0.01 \\
\hline
\end{tabular}

Table 5: Dependent variable is the separation rate (total separations in percent of employment). Robust standard errors are clustered at the establishment level. $* * * / * * *$ denotes $1 / 5 / 10$ percent significance. Employment dummies represent the following categories: 0-9, 10-49, 50-199, 200+ employees (0-9 is base category). Sectoral dummies represent manufacturing, construction, services and others (services is base category). 


\begin{tabular}{|c|c|c|c|c|c|}
\hline & \multicolumn{3}{|c|}{ Interaction with WTA only and size } & \multicolumn{2}{|c|}{ Interaction with sector } \\
\hline & (1) & (2) & (3) & & (4) \\
\hline $\log$ revenue & $\begin{array}{c}-0.316 \\
{[0.71]}\end{array}$ & $\begin{array}{c}-0.250 \\
{[0.76]}\end{array}$ & $\begin{array}{c}-0.004 \\
{[0.83]}\end{array}$ & $\log$ revenue & $\begin{array}{c}0.302 \\
{[0.84]}\end{array}$ \\
\hline revenue $\times$ WTA & $\begin{array}{c}1.165 \\
{[1.11]}\end{array}$ & $\begin{array}{c}0.214 \\
{[1.22]}\end{array}$ & $\begin{array}{c}0.201 \\
{[1.91]}\end{array}$ & revenue $\times$ WTA & $\begin{array}{c}0.192 \\
{[1.59]}\end{array}$ \\
\hline revenue $\times D_{2}^{e m p}$ & & & $\begin{array}{c}-0.176 \\
{[1.35]}\end{array}$ & revenue $\times D_{2}^{\text {sector }}$ & $\begin{array}{c}-1.452 \\
{[1.24]}\end{array}$ \\
\hline revenue $\times D_{3}^{e m p}$ & & & $\begin{array}{c}0.112 \\
{[2.25]}\end{array}$ & revenue $\times D_{3}^{\text {sector }}$ & $\begin{array}{r}-1.217 \\
{[1.58]}\end{array}$ \\
\hline revenue $\times D_{4}^{e m p}$ & & & $\begin{array}{c}-0.233 \\
{[1.89]}\end{array}$ & revenue $\times D_{4}^{\text {sector }}$ & $\begin{array}{c}-1.191 \\
{[2.00]}\end{array}$ \\
\hline revenue $\times D_{2}^{e m p} \times$ WTA & & & $\begin{array}{c}0.935 \\
{[2.31]}\end{array}$ & revenue $\times D_{2}^{\text {sector }} \times$ WTA & $\begin{array}{c}1.134 \\
{[1.47]}\end{array}$ \\
\hline revenue $\times D_{3}^{e m p} \times \mathrm{WTA}$ & & & $\begin{array}{c}0.055 \\
{[2.92]}\end{array}$ & revenue $\times D_{3}^{\text {sector }} \times$ WTA & $\begin{array}{r}0.065 \\
{[2.06]}\end{array}$ \\
\hline revenue $\times D_{4}^{e m p} \times$ WTA & & & $\begin{array}{c}-0.358 \\
{[2.63]}\end{array}$ & revenue $\times D_{4}^{\text {sector }} \times$ WTA & $\begin{array}{c}0.373 \\
{[2.07]}\end{array}$ \\
\hline employees & $\begin{array}{l}-0.006^{* * *} \\
{[0.002]}\end{array}$ & $\begin{array}{c}-0.007^{* *} \\
{[0.003]}\end{array}$ & $\begin{array}{c}-0.006^{* *} \\
{[0.003]}\end{array}$ & employees & $\begin{array}{c}-0.007^{* *} \\
{[0.003]}\end{array}$ \\
\hline works council & & $\begin{array}{c}-0.529 \\
{[1.27]}\end{array}$ & $\begin{array}{c}-0.491 \\
{[1.27]}\end{array}$ & works council & $\begin{array}{r}-0.617 \\
{[1.32]}\end{array}$ \\
\hline collective wages & & $\begin{array}{c}-0.876 \\
{[0.69]}\end{array}$ & $\begin{array}{c}-0.869 \\
{[0.69]}\end{array}$ & collective wages & $\begin{array}{c}-0.840 \\
{[0.74]}\end{array}$ \\
\hline agency workers & & $\begin{array}{c}0.001 \\
{[0.01]}\end{array}$ & $\begin{array}{l}0.0004 \\
{[0.01]}\end{array}$ & agency workers & $\begin{array}{c}0.001 \\
{[0.01]}\end{array}$ \\
\hline temporary workers & & $\begin{array}{l}0.368^{* * *} \\
{[0.37]}\end{array}$ & $\begin{array}{l}0.368^{* * *} \\
{[0.05]}\end{array}$ & temporary workers & $\begin{array}{l}0.373^{* * *} \\
{[0.06]}\end{array}$ \\
\hline high skilled & & $\begin{array}{c}0.009 \\
{[0.02]}\end{array}$ & $\begin{array}{c}0.008 \\
{[0.02]}\end{array}$ & high skilled & $\begin{array}{c}0.009 \\
{[0.02]}\end{array}$ \\
\hline export share & & $\begin{array}{l}0.032^{*} \\
{[0.02]}\end{array}$ & $\begin{array}{l}0.032^{*} \\
{[0.02]}\end{array}$ & export share & $\begin{array}{l}0.033^{*} \\
{[0.02]}\end{array}$ \\
\hline women & & $\begin{array}{c}0.013 \\
{[0.02]}\end{array}$ & $\begin{array}{c}0.013 \\
{[0.02]}\end{array}$ & women & $\begin{array}{c}0.015 \\
{[0.02]}\end{array}$ \\
\hline year $=2009$ & $\begin{array}{l}-1.785^{* * *} \\
{[0.28]}\end{array}$ & $\begin{array}{l}-1.656^{* * *} \\
{[0.28]}\end{array}$ & $\begin{array}{l}-1.649^{* * *} \\
{[0.28]}\end{array}$ & year $=2009$ & $\begin{array}{l}-1.725^{* * *} \\
{[0.30]}\end{array}$ \\
\hline year $=2010$ & $\begin{array}{c}-1.299 \\
{[0.30]}\end{array}$ & $\begin{array}{c}-1.186^{* * *} \\
{[0.30]}\end{array}$ & $\begin{array}{c}-1.179^{* * *} \\
{[0.30]}\end{array}$ & year $=2010$ & $\begin{array}{c}-1.265^{* * *} \\
{[0.32]}\end{array}$ \\
\hline observations & 10,394 & 10,135 & 10,135 & observations & 9,822 \\
\hline establishments & 4,228 & 4,211 & 4,211 & establishments & 4,181 \\
\hline$R^{2}$ (within) & 0.01 & 0.06 & 0.06 & $R^{2}$ (within) & 0.06 \\
\hline
\end{tabular}

Table 6: Dependent variable is the hiring rate (total hirings in percent of employment). Robust standard errors are clustered at the establishment level. $* * * / * * * *$ denotes $1 / 5 / 10$ percent significance. Employment dummies represent the following categories: 0-9, 10-49, 50-199, 200+ employees (09 is base category). Sectoral dummies represent manufacturing, construction, services and others (services is base category). 


\begin{tabular}{|c|c|c|c|c|c|}
\hline & \multicolumn{3}{|c|}{ Interaction with WTA only and size } & \multicolumn{2}{|c|}{ Interaction with sector } \\
\hline & $(1)$ & $(2)$ & (3) & & (4) \\
\hline $\log$ revenue & $\begin{array}{l}-2.066^{* * *} \\
{[0.68]}\end{array}$ & $\begin{array}{l}-2.067^{* * *} \\
{[0.71]}\end{array}$ & $\begin{array}{c}-1.140 \\
{[0.71]}\end{array}$ & $\log$ revenue & $\begin{array}{c}-1.108 \\
{[0.70]}\end{array}$ \\
\hline revenue $\times$ WTA & $\begin{array}{l}-10.486^{* * *} \\
{[1.82]}\end{array}$ & $\begin{array}{l}-9.835^{* * *} \\
{[1.88]}\end{array}$ & $\begin{array}{c}-7.466^{*} \\
{[3.84]}\end{array}$ & revenue $\times$ WTA & $\begin{array}{l}-8.971^{* * *} \\
{[1.75]}\end{array}$ \\
\hline revenue $\times D_{2}^{e m p}$ & & & $\begin{array}{l}-4.473^{* * *} \\
{[1.48]}\end{array}$ & revenue $\times D_{2}^{\text {sector }}$ & $\begin{array}{l}-3.606^{* * *} \\
{[0.91]}\end{array}$ \\
\hline revenue $\times D_{3}^{e m p}$ & & & $\begin{array}{r}-3.367 \\
{[2.40]}\end{array}$ & revenue $\times D_{3}^{\text {sector }}$ & $\begin{array}{l}-2.052^{* *} \\
{[0.92]}\end{array}$ \\
\hline revenue $\times D_{4}^{e m p}$ & & & $\begin{array}{c}-5.148^{* *} \\
{[2.24]}\end{array}$ & revenue $\times D_{4}^{\text {sector }}$ & $\begin{array}{c}-2.199^{*} \\
{[1.26]}\end{array}$ \\
\hline revenue $\times D_{2}^{e m p} \times$ WTA & & & $\begin{array}{l}1.527 \\
{[4.09]}\end{array}$ & revenue $\times D_{2}^{\text {sector }} \times$ WTA & $\begin{array}{c}0.816 \\
{[1.57]}\end{array}$ \\
\hline revenue $\times D_{3}^{e m p} \times \mathrm{WTA}$ & & & $\begin{array}{c}-1.507 \\
{[4.59]}\end{array}$ & revenue $\times D_{3}^{\text {sector }} \times$ WTA & $\begin{array}{r}1.607 \\
{[1.56]}\end{array}$ \\
\hline revenue $\times D_{4}^{e m p} \times$ WTA & & & $\begin{array}{c}1.246 \\
{[4.65]}\end{array}$ & revenue $\times D_{4}^{\text {sector }} \times \mathrm{WTA}$ & $\begin{array}{c}2.251 \\
{[1.54]}\end{array}$ \\
\hline employees & $\begin{array}{l}0.014^{* *} \\
{[0.006]}\end{array}$ & $\begin{array}{l}0.016^{* * *} \\
{[0.006]}\end{array}$ & $\begin{array}{l}0.017^{* * *} \\
{[0.006]}\end{array}$ & employees & $\begin{array}{l}0.016^{* *} \\
{[0.006]}\end{array}$ \\
\hline works council & & $\begin{array}{c}2.694 \\
{[2.22]}\end{array}$ & $\begin{array}{c}2.499 \\
{[2.20]}\end{array}$ & works council & $\begin{array}{c}2.377 \\
{[2.26]}\end{array}$ \\
\hline collective wages & & $\begin{array}{c}-0.896 \\
{[0.87]}\end{array}$ & $\begin{array}{c}-0.853 \\
{[0.87]}\end{array}$ & collective wages & $\begin{array}{c}-0.939 \\
{[0.89]}\end{array}$ \\
\hline agency workers & & $\begin{array}{c}-0.130^{* * *} \\
{[0.05]}\end{array}$ & $\begin{array}{c}-0.132^{* * *} \\
{[0.05]}\end{array}$ & agency workers & $\begin{array}{c}-0.125^{* *} \\
{[0.05]}\end{array}$ \\
\hline temporary workers & & $\begin{array}{c}-0.101^{* *} \\
{[0.04]}\end{array}$ & $\begin{array}{l}-0.100^{* *} \\
{[0.04]}\end{array}$ & temporary workers & $\begin{array}{c}-0.103^{* *} \\
{[0.04]}\end{array}$ \\
\hline high skilled & & $\begin{array}{l}0.050^{* *} \\
{[0.03]}\end{array}$ & $\begin{array}{c}-0.049^{*} \\
{[0.03]}\end{array}$ & high skilled & $\begin{array}{l}0.052^{* *} \\
{[0.03]}\end{array}$ \\
\hline export share & & $\begin{array}{c}-0.087^{*} \\
{[0.05]}\end{array}$ & $\begin{array}{c}-0.088^{*} \\
{[0.05]}\end{array}$ & export share & $\begin{array}{c}-0.078^{*} \\
{[0.05]}\end{array}$ \\
\hline women & & $\begin{array}{c}-0.029^{*} \\
{[0.02]}\end{array}$ & $\begin{array}{c}-0.031^{*} \\
{[0.02]}\end{array}$ & women & $\begin{array}{c}-0.025 \\
{[0.02]}\end{array}$ \\
\hline year $=2009$ & $\begin{array}{l}7.825^{* * *} \\
{[0.43]}\end{array}$ & $\begin{array}{l}7.544^{* * *} \\
{[0.43]}\end{array}$ & $\begin{array}{l}7.572^{* * *} \\
{[0.43]}\end{array}$ & year $=2009$ & $\begin{array}{l}7.802^{* * *} \\
{[0.46]}\end{array}$ \\
\hline year $=2010$ & $\begin{array}{l}6.956^{* * *} \\
{[0.40]}\end{array}$ & $\begin{array}{l}6.832^{* * *} \\
{[0.41]}\end{array}$ & $\begin{array}{l}6.915^{* * *} \\
{[0.41]}\end{array}$ & year $=2010$ & $\begin{array}{l}7.073^{\text {*** }} \\
{[0.43]}\end{array}$ \\
\hline observations & 10,441 & 10,178 & 10,178 & observations & 9,863 \\
\hline establishments & 4,231 & 4,214 & 4,214 & establishments & 4,183 \\
\hline$R^{2}$ (within) & 0.09 & 0.09 & 0.09 & $R^{2}$ (within) & 0.09 \\
\hline
\end{tabular}

Table 7: Dependent variable is the number of short-time workers over total employees. Robust standard errors are clustered at the establishment level. $* * * / * * / *$ denotes $1 / 5 / 10$ percent significance. Employment dummies represent the following categories: 0-9, 10-49, 50-199, 200+ employees (09 is base category). Sectoral dummies represent manufacturing, construction, services and others (services is base category). 